University of Nebraska - Lincoln

DigitalCommons@University of Nebraska - Lincoln

Faculty Publications from the Harold W. Manter Laboratory of Parasitology

1951

Biotic Interrelationships of Helminth Parasitism

Robert L. Rausch

University of Washington, rausch@u.washington.edu

Follow this and additional works at: https://digitalcommons.unl.edu/parasitologyfacpubs

Part of the Parasitology Commons

Rausch, Robert L., "Biotic Interrelationships of Helminth Parasitism" (1951). Faculty Publications from the Harold W. Manter Laboratory of Parasitology. 561.

https://digitalcommons.unl.edu/parasitologyfacpubs/561

This Article is brought to you for free and open access by the Parasitology, Harold W. Manter Laboratory of at DigitalCommons@University of Nebraska - Lincoln. It has been accepted for inclusion in Faculty Publications from the Harold W. Manter Laboratory of Parasitology by an authorized administrator of DigitalCommons@University of Nebraska - Lincoln. 


\section{Biotic Interrelationships of Helminth Parasitism}

By Robert Rausch, Senior Assistant Scientist

Biotic interrelationships in Alaska have so far suffered little from man's attempts to improve upon nature. As a result of these favorable circumstances, biological investigation in Alaska offers unusual opportunity for elucidating problems which can no longer be approached in the more populated parts of North America. One is very fortunate to have the opportunity of working under these conditions, 
since present trends indicate that Alaska is soon to go by the way of the great wildernesses which once existed in the United States and Canada.

The following observations and conclusions are based upon the autopsies of more than 4,000 Alaskan birds and mammals, supplemented by field studies over much of the Territory. These observations are further substantiated by about 6,000 additional autopsies which I completed in the United States and Canada during the 8 years preceding the Alaskan work. This background work allows direct comparison of arctic conditions with those in warmer regions and contributes to the understanding of helminth parasitism in Alaska.

\section{Parasites Found in Alaska}

Certain general conclusions may be drawn in regard to occurrence of worm parasites in Alaska. It is evident that cestodes comprise the most abundant and varied group in both migratory and nonmigratory birds and, to a lesser degree, in mammals. Trematodes are relatively uncommon, particularly in arctic regions, although a few species occur commonly in marine mammals. We assume that the comparative lack of snail intermediate hosts, particularly in the more northern regions, contributes largely to this situation. One rarely finds these parasites even in such birds as loons and ducks, usualiy heavily infected with trematodes farther south. Strigeid trematodes are rare, although farther south, in the United States and southern Canada, they occur commonly in various aquatic and predatory birds. Parasitic nematodes are often numerically abundant, but the number of species is relatively small. In both arctic and subarctic regions, the diversity of species is much less than that found at lower latitudes. Certain genera are completely lacking, although they may comprise the major part of the helminth fauna of the same host farther south.

We have evidence that birds nesting in arctic regions, but wintering much farther south, are usually infected by cestodes while on the breeding grounds as nestlings or nonflying immatures. We have observed this especially among ducks and among other water birds such as gulls. Earlier observations on birds in the central and western United States support the conclusion that helminth infections are obtained essentially before migration takes place.

One of the factors which contributes to the interest of studies of this type in Alaska is the occurrence of a considerable number of mammals which are circumpolar in distribution. Comparisons can be made of the parasites of a given host on both continents, and this may lead to information of zoogeographical significance. As an example, some of the parasites of microtine rodents, such as Heligmosomum costellatum Dujardin, Hymenolepis horrida (von Linstow), 
and Paranoplocephala omphalodes (Hermann), may be cited. These, with several other species, have been recovered from Alaskan voles and lemmings and are well-known Eurasian species, never having been reported from North America. Some earlier work in the Rockies (5) disclosed the presence of $H$. horrida and $H$. costellatum in voles in the subalpine zone. I have also recovered specimens of $H$. horrida from Microtus ochrogaster from the Great Smoky Mountains in Tennessee. This would seem to indicate that such parasites are relict forms, isolated in various southern mountain masses.

Although such parasites are found over much of Alaska, even in the lower, timbered country, they appear so far to have been unable to exceed the limitations of alpine and subalpine conditions farther south in the temperate regions of the continent. Observations to date indicate that $P$. omphalodes is limited to Arctic Alaska; however, it cannot be considered an arctic species, since it occurs southward well into Europe. This species may be a relatively recent invader from Eurasia and, so far, is limited to microtine rodents recently invading North America from the other continent-that is, Microtus miurus and other voles of the Stenocranius group, and Microtus oeconomus (6) -none of which has extended its range in North America beyond Alaska and northwestern Canada.

In microtine rodents and in many other mammals as well, we have collected helminths of species occurring farther south in Canada and the United States. However, we also have found several species which are new to the fauna of both North America and Eurasia (2, 10, $13,14,15,18,19)$. Some of these may occur in Siberia also, but this is unknown at present.

\section{Survive Arctic Climate}

The arctic climate does not necessarily have the effect on helminth parasites that one might expect, even though the complexity of their life cycles might lead to the conclusion that they would be vulnerable to climatic extremes. In fact, the evidence we have to date would indicate that many of the species occurring much farther south are able to exist very successfully under arctic conditions. For example, the tapeworms Parnoplocephala infrequens Douthitt and Andrya primordialis Douthitt occur commonly in the Arctic. We have taken the former, which has also been recorded from Siberian rodents, from as far north as Point Barrow, and we have specimens of the latter from Prince Patrick Island, north of latitude $75^{\circ} \mathrm{N}$. Both species occur commonly over the United States. Other species found commonly much farther south, such as Andrya macrocephala Douthitt and Syphacia obvelata (Rudolphi), occur in Arctic and sub-Arctic Alaska, and in Siberia. We have recovered both species from as far south as Mexico City, where they occur in Microtus mexicanus. 
Observations on the parasites of lemmings during the time of cyclic high population density (9) bear out earlier conclusions that, for microtine rodents, at least, there is no increase of worm parasites accompanying a great increase in host numbers (12).

\section{Trichinosis in Marine Mammals}

Some phases of the epizootiology of forms having much public health significance are not understood. It has been established that trichinosis is found in marine mammals, including the white whale and various seals, but the mode of transmission to them is completely unknown. The feeding habits of marine mammals, according to our present knowledge, would seem to preclude any opportunity for infection with Trichinella spiralis, since they are known to eat only fishes and various marine invertebrates, none of which can be infected with this parasite, as far as is known. We have thought that such animals might consume infected lemmings or other small rodents, which often gain entrance to the sea, particularly during times of cyclic high populations (3). Thus, the infection might be transmitted directly, or indirectly by the consumption of fishes which had fed upon infected lemmings. However, the examination of hundreds of such rodents has failed to disclose a single infection. It should be kept in mind, however, that a very small percentage of the population could be infected and still allow a considerable actual number of infected individuals. At times, lemmings reach such a high population density along the Arctic Coast that a few hundred would not be an adequate sample. We propose to study this situation more thoroughly during the next lemming high, expected during the spring of 1952 .

It is possible that the strain of Trichinella found in the Arctic differs somewhat from that farther south in its ability to withstand low temperatures. We have no controlled observations on this as yet, but field observations would seem to bear out this impression. We expect to study the problem further this year, under both laboratory and natural conditions. Since much of the meat eaten by the Eskimos is first stored in cellars excavated from the permanently frozen soil, it seems desirable to determine the effect of such conditions on the survival of Trichinella larvae.

Trichinosis in the human population of Alaska represents a definite public health problem. Our observations so far seem to indicate that human infections may be contracted through the consumption of the flesh of marine mammals, which furnishes the bulk of meat consumed and is frequently eaten raw. Little pork or meat from other animals which might transmit trichinosis is available. The only carnivorous animals which might be involved would be the polar bear and the arctic grizzly (Ursus richardsoni), both of which are obtained from 
time to time. It is the general custom of the Eskimos along the Arctic Coast to cook the flesh of bears.

The high prevalence of trichinosis infection in polar bears, as reported in the literature and on the basis of personal observations, would seem to support the hypothesis that they become infected from eating seals - their most important food source. The high prevalence seen also in land carnivores appears to be a direct result of natural predatory habits (1). Thorburg, Tulinius, and Roth (17) have discussed trichinosis in marine mammals in Greenland.

'The Eskimos on Saint Lawrence Island depend almost exclusively upon the flesh of sea mammals for food, to a degree considerably greater than is now the case along the Arctic Coast of Alaska. The rarity of the polar bear and the absence of any other land mammal which is used for food would indicate that trichinosis here is transmitted also by sea mammals to man. I have observed numerous trichinosis infections among the Saint Lawrence Island dogs, which are also fed largely upon the flesh of walrus and various species of seals. It is possible that dogs might become infected from consuming infected carcasses of the arctic fox, although in view of present information this would seem unlikely.

Speciation on the basis of morphological characters of tapeworms of the genus Diphyllobothrium is impossible for Alaskan forms. This precludes any concept of host specificity and prevents any attempt at the control of human infections from an epidemiological standpoint. We are conducting life cycle and animal infection studies in an attempt to clarify these problems.

\section{Tapeworm Infections}

The interrelationship of man-dog-ruminant (i. e., caribou and moose) in Arctic Alaska contributes much to the possibility of human Echinococcus infection. On the mainland the epidemiological pattern is typical. However, the importance of small rodents (Microtus) as intermediate hosts of this parasite is not understood. The fact that these voles serve as the predominant intermediate host on Saint Lawrence Island and our failure to find infected animals of the same and closely related species on the mainland is of unusual interest (11). Two factors may be considered: either we are dealing with two species of parasite, both of which infect man, or the situation is greatly affected by the population dynamics of the fox and rodent hosts. As is well known, arctic rodent populations are in a constant state of fluctuation, so that they differ each given year within the approximately 4-year cycle period. Also, where two or more species of small microtine rodent (e. g., Lemmus, Dicrostonyx, Clethrionomys, and Microtus) occur together, their cycles usually are not in phase. Thus, while a given species may be very abundant, others in the same region may be 
very rare. This requires long-term investigation of each species, and adequate material for study is only obtainable under these conditions. There has been considerable controversy in the past regarding speciation of Echinococcus. According to the work of Henschen and Bircher (4), in Europe, at least two species are clearly recognizable. We have yet to eliminate this possibility, particularly by means of experimental infections. Another point of much interest is the apparent rapid growth of these Echinococcus cysts in the rodent intermediate host. According to presently available information, the usual life span of voles of the genus Microtus is believed to be only about a year. This does not seem to be in accord with the usual concept of the rate of development of the Echinococcus cyst. We expect to clarify these points by experimenta] work.

If conditions in Alaska are allowed to remain relatively unchanged in regard to biotic interrelationships, there should be opportunity for the clarification of various public health problems of considerable importance in more northern climates. Such work as outlined in this paper is only possible under conditions of an undisturbed ecology.

\section{REFERENCES}

(1) Brandly, P. J., and Rausch, Robert: Preliminary report on trichinosis in Alaska. Arctic 3: 105-107 (1950).

(2) Dubois, G., and Rausch, Robert: Troisieme contribution a l'etude des strigeides (Trematoda) Nord-Americains. Bull. Soc. Neuchat. Sc. Nat. 73: $19-50$ (1950).

(3) Elton, C.: Voles, Mice, and Lemmings. Oxford, 1942, $496 \mathrm{pp}$.

(4) Henschen, C., and Bircher, R.: Zur Epidemiologie, Pathologie und Chirurgie des Echinococcus alveolaris. Bull. Schweiz. Akad. d. med. Wissensch. 1: 209-224 (1945).

(5) Kuns, M., and Rausch, Robert: An ecological study of helminths of some Wyoming voles (Microtus spp.) with a description of a new species of Nematospiroides (Heligmosomidae: Nematoda). Zoologica 35: 181-188 (1950).

(6) Rausch, Robert: Notes on microtine rodents from the Brooks Range, Arctic Alaska. J. Wash. Acad. Sc. 40: 133-136 (1950).

(7) Rausch, Robert: Notes on the distribution of some arctic mammals. J. Mammal. 31: 464-466 (1950).

(8) Rausch, Robert: Studien an der Helminthenfauna von Alaska. IV. Haploparaxis galli $\mathrm{n}$. sp. ein Cestode aus dem Schneehuhn, Lagopus rupestris (Gmelin). Ztschr. Parasitenk. 15: 1-3 (1951).

(9) Rausch, Robert: Observations on a cyclic decline of lemmings (Lemmus) at Point Barrow, Alaska, during the spring of 1949. Arctic 3: 166-177 (1951).

(10) Rausch, Robert, and Locker, Betty: Studies on the helminth fauna of Alaska. II. On some helminths parasitic in the sea otter Enhydra lutris, (L.). Proc. Helm. Soc. Washington. 18: 77-81 (1951).

(11) Rausch, Robert, and Schiller, E. L.: Hydatid disease (Echinococcosis) in Alaska, and the importance of rodent intermediate hosts. Science 113: $57-58$ (1951).

(12) Rausch, Robert, and Tiner, Jack D.: Studies on the parasitic helminths of the North Central States. II. Helminths of voles (Microtus spp.). Preliminary report. Am. Midl. Nat. 41: 665-694 (1949).

(13) Schiller, E. L.: Studies on the helminth fauna of Alaska. I. Two new cestodes from Sabine's gull, Xema sabini. J. Parasitol. (in press).

(14) Schiller, E. L.: Studies on the helminth fauna of Alaska. III. Hymenolepis kenaiensis n. sp. a cestode from the greater scaup (Aythya marila nearctica) with remarks on endemicity. Trans. Am. Microbiol. Soc. (in press).

July 20, 1951 
(15) Schiller, E. L.: Studies on the helminth fauna of Alaska. VI. The parasites of the emperor goose (Philacte canagica L.) with the description of Hymenolepis philactes, n. sp. J. Parasitol. 37: 217-220 (1951).

(16) Schiller, E. L.: Cestoda of anseriformes of the North Central States. Am. Midl. Nat (in press).

(17) Thorborg, N. B., Tuliuius, S., and Roth, H.: Trichinosis in Greenland. Acta path. Microbiol. Scandinav. 25: 778-794 (1948).

(18) Tiner, J. D., and Rausch, Robert: Two new Syphacia (Nematoda: Oxyuridae) and observations on the inner circle circumoral papillae in North American species of the genus. Nat. Hist. Misc. No. 57, pp. 1-6, 1950.

(19) Van Cleave, H. J., and Rausch, Robert: A new species of the acanthocephalan genus Arhythmorhynchus from sandpipers of Alaska. J. Parasitol. 36: 278-282 (1950).

(20) Van Cleave, H. J., and Rausch, Robert: The acanthocephalan parasites of eider ducks. Proc. Helm. Soc. Washington. 18: 81-84 (1951). 